\title{
EFFECT OF GROWTH REGULATORS ON THE POSTHARVEST LONGEVITY OF CUT FLOWERS AND LEAVES OF THE CALLA LILY (Zantedeschia Spreng.)
}

\author{
Beata Janowska, Anna Stanecka \\ Department of Ornamental Plants, University of Life Sciences in Poznań, Dąbrowskiego 159, 60-594 Poznań, Poland \\ e-mail: beataj@up.poznan.pl
}

Received: 10.07.2011

\begin{abstract}
The conditioning of flowers of the calla lily cultivar 'Albomaculata' in BA at concentrations of $50-150 \mathrm{mg} \times \mathrm{dm}^{-3}$ extends their postharvest longevity by 6.2-14.5 days. An extension of the longevity of the flowers by 15 days can be obtained after the application of a solution of $8 \mathrm{HQS}$ with saccharose on a continuous basis. Effective in improving the longevity of leaves of cultivar 'Sunglow' is $\mathrm{GA}_{3}$ at a concentration of $400 \mathrm{mg} \times \mathrm{dm}^{-3}$. What is more, its application at concentrations of $300-400 \mathrm{mg} \times \mathrm{dm}^{-3}$ boosts their greenness index. $\mathrm{GA}_{3}$ at concentrations of 50 and $100 \mathrm{mg} \times \mathrm{dm}^{-3}$ extends the postharvest longevity of leaves of the cultivar 'Black Eyed Beauty' by 18 and 11 days, respectively, while BA shortens it. A combined application of $\mathrm{BA}$ and $\mathrm{GA}_{3}$ inhibits chlorophyll degradation, while $\mathrm{GA}_{3}$ and a mixture of $\mathrm{BA}$ and $\mathrm{GA}_{3}$ inhibit protein degradation.
\end{abstract}

Key words: Zantedeschia, flowers, florist' greens, vase-life, $\mathrm{BA}, \mathrm{GA}_{3}, 8 \mathrm{HQS}$

\section{INTRODUCTION}

In the recent years, research has increasingly focused on the postharvest longevity of both flowers and florist greens, which have become an indispensable element of modern flower arrangements. So far, only a few studies have been made on cut flowers and leaves of the calla lily. T ji a and Funnell (1986) report that the vase life of Zantedeschia aethiopica flowers lasts 6-7 days after cutting, while in Zantedeschia elliottiana the spathes turn green after 7-8 days, which is a visible symptom of the advancing process of senescence. Besides, peduncles placed in pure water tend to split and, to prevent it, the authors recommend an addition of sugar and 8-hydroxyquinoline citrate. However, as Łukaszewska and Kokosa (1997) report, in Zantedeschia aethiopica sugar added to the medium brings about a rapid drop in the hydration level of tissues and the appearance of necrotic spots on spathes. In a research by J a nowska and Jerzy (2004), the splitting of peduncles was not observed in cultivars 'Florex Gold' and 'Black Magic', while the greening of spathes appeared only in the cultivar 'Florex Gold'. The authors also obtained very good postharvest longevity in flowers, which kept their ornamental qualities for about 3-4 weeks after being placed in water. However, an undesirable development was the rotting of peduncle ends in the cultivar 'Black Magic' as a result of conditioning in a solution of 8-hydroxyquinoline citrate. Moreover, this practice shortened the postharvest vase-life of flowers by 7-8 days. Ornamental qualities were preserved the longest by those flowers which had been placed after cutting in solutions of gibberellic acid at concentrations of 50 and $100 \mathrm{mg} \times \mathrm{dm}^{-3}$. In the cultivar 'Florex Gold', postharvest longevity was the best in flowers which had been conditioned in a solution of 8-hydroxyquinoline citrate for 2 hours. In this cultivar, gibberellic acid also proved effective in extending longevity, because irrespective of the duration of conditioning in the solution of 8-hydroxyquinoline citrate, the flowers that had been then placed in solutions of this acid preserved their ornamental qualities several days longer.

There has been little research so far on the postharvest longevity of leaves of the calla lily. J a n ow ska and J e r z y (2003a) obtained the most extended vase-life in leaves of the cultivars 'Florex Gold' and 'Black Magic' by conditioning them in solutions of gibberellic acid at concentrations of 200 and $300 \mathrm{mg} \times \mathrm{dm}^{-3}$. Moreover, improved longevity also involved slower chlorophyll degradation (J a n o w s k a and J e r z y, 2003b). Similarly, in Zantedeschia aethiopica gibberellic acid proved effective in extending the postharvest longevity 
of leaves: it caused leaf longevity to increase as much as sixfold ( $\mathrm{Eukaszewska，2000;} \mathrm{Skutnik} \mathrm{et}$ al. 2004).

The aim of the present research was to assess the effect of conditioning of flowers in a water solution of benzyladenine and a standard flower preservative, containing 8-hydroxyquinoline sulphate (8HQS) and $2 \%$ saccharose, on the postharvest longevity of calla lily flowers of the cultivar 'Albomaculata' and to assess the effect of benzyladenine and gibberellic acid on the postharvest longevity of leaves of the cultivars 'Sunglow' and 'Black Eyed Beauty'.

\section{MATERIAL AND METHODS}

The research was conducted in the Department of Ornamental Plants of the University of Life Sciences in Poznań from July to August 2007. The cultivars employed were 'Albomaculata' and 'Black Eyed Beauty' deriving from the spotted calla (Zantedeschia albomaculata /Hook./ Baill.) as well as 'Sunglow' deriving from Zantedeschia sp.

Flowers were conditioned for 4 hours in water solutions of benzyladenine at concentrations of 50,100 , and $150 \mathrm{mg} \times \mathrm{dm}^{-3}$. They were then placed in distilled water or in an water solution of 8-hydroxyquinoline sulphate $(8 \mathrm{HQS})$ at a concentration of $200 \mathrm{mg} \times \mathrm{dm}^{-3}$ with an addition of $2 \%$ saccharose. The control was flowers put in distilled water. The acidity of the solutions was $\mathrm{pH} \pm 5$. During the experiment, water was changed every day and the aqueous $8 \mathrm{HQS}$ solutions were supplemented with saccharose to fill up.

The experiment consisted of 8 treatments, each involving 5 plants in 3 replications. One treatment (BA concentration $\mathrm{x}$ the longevity-improving solution) consisted of 15 flowers.

The postharvest longevity of the flowers was determined in days. The loss of their ornamental qualities was set at that point in time when they had turned green or when the tops of the spathes had dried. In the calla lily, a "flower" is a conventional simplifying term used to describe the inflorescence on a peduncle a spadix - surrounded by a spathe.

Leaves of the cultivar 'Sunglow' were conditioned for 4 hours in water solutions of $\mathrm{GA}_{3}$ at concentrations of 300 and $400 \mathrm{mg} \times \mathrm{dm}^{-3}$. They were then placed in distilled water or in aqueous solutions of BA at concentrations of 50 and $100 \mathrm{mg} \times \mathrm{dm}^{-3}$. The control was leaves put in distilled water.

The experiment consisted of 9 treatments, each involving 5 leaves in 3 replications. One treatment $\left(\mathrm{GA}_{3}\right.$ concentration $\mathrm{x}$ BA concentration) consisted of 15 leaves.

Leaves of the cultivar 'Black Eyed Beauty' with petioles shortened to $40 \mathrm{~cm}$ were conditioned for
12 hours in a cold room at $5^{\circ} \mathrm{C}$. The conditioning involved water solutions of benzyladenine and gibberellic acid at the same concentrations of 50 and $100 \mathrm{mg} \times \mathrm{dm}^{-3}$ as well as those in which the growth regulators had a concentration of 50 or $100 \mathrm{mg} \times \mathrm{dm}^{-3}$. After conditioning, the leaves were placed in distilled water. The control was leaves put in distilled water.

The postharvest longevity of the leaves was determined in days. The loss of their ornamental qualities was set at that point in time when they had turned yellow or when $30 \%$ of the leaf blades had wilted. Their greenness index, measured in SPAD units using a SPAD-502 Chlorophyll Meter (G r e g o r c z y k and R a c zy ń ska, 1997; Gre g orczy k et al. 1998), as well as their content of chlorophylls $a+b$ and proteins were determined. Noted was the initial index of leaf greenness measured at the start of the experiment as well as the initial content of chlorophylls $a+b$ and proteins in the leaves.

The chlorophyll level was determined using the method presented in $\mathrm{Hiscox}$ and Is raelstam (1979). It allows extracting pigments from plant material with the help of dimethyl sulphoxide (DMSO) without tissue maceration. Weighted portions were treated with $15 \mathrm{ml}$ DMSO and incubated in a water bath at $65^{\circ} \mathrm{C}$ for 60 minutes. In the extract thus obtained, the level of chlorophylls $a+b$ was determined spectrophotometrically. The total of chlorophylls $a+b$ was calculated following ARNON (1949). The amounts of the individual pigments were given in $\mathrm{mg} \times \mathrm{g}^{-1}$ fresh weight.

The determination of protein content in the leaves was made with the help of B r a d f ord's (1976) method. $2 \mathrm{ml}$ of a solution of Coomassie Brilliant Blue G-250 (CBB) in $85 \%$ orthophosphoric acid was added to $100 \mu \mathrm{l}$ of a diluted extract, with the extraction in a phosphorate-potassium buffer ( $\mathrm{pH}$ 7.0). After $10 \mathrm{mi}$ nutes the absorbance was measured at a wavelength of $595 \mathrm{~nm}$. Protein content was determined from a curve plotted for albumin.

The experiments were conducted at a temperature of $18-20^{\circ} \mathrm{C}$ and a $12-\mathrm{h}$ photoperiod, employing white luminescence light with a quantum irradiance intensity of $25 \mu \mathrm{mol} \mathrm{m} \mathrm{s}^{-1}$. The relative air humidity was maintained at $70 \%$.

The results were processed with the help of univariate analysis of variance. The means were grouped using Duncan's test at the $a=0.05$ significance level.

\section{RESULTS}

The postharvest longevity of flowers of the cultivar 'Albomaculata' depended on both the concentration of benzyladenine applied for conditioning and the solution used after it (Table 1). Whether the flowers 
were placed in water after the conditioning or in a solution of 8-hydroxyquinoline sulphate with saccharose, the longest-lived were those which had been conditioned in benzyladenine at concentrations of 50 or $150 \mathrm{mg} \times \mathrm{dm}^{-3}$. When comparing interactions between the factors, it was found that the greatest effect on the longevity of cut flowers of the calla lily was produced by their four-hour conditioning in the solution of benzyladenine at a concentration of $50 \mathrm{mg} \times \mathrm{dm}^{-3}$ and then putting them in water, as well as by their direct placement in the aqueous solution of 8-hydroxyquinoline sulphate with saccharose without conditioning. In both cases, the vase-life of the flowers was about 25 days. In comparison with the control, their longevity grew by 14.5 and 15.0 days, respectively. The combination of flower conditioning in the solution of benzyladenine at $50 \mathrm{mg} \times \mathrm{dm}^{-3}$ followed by their placement in the solution of $8 \mathrm{HQS}$ with saccharose reduced the effec- tiveness of both practices and shortened the longevity of the flowers to 20.3 days. An extension of the vase-life of flowers by about 10-11 days was obtained by conditioning them in benzyladenine at $150 \mathrm{mg} \times \mathrm{dm}^{-3}$, irrespective of the kind of solution to which they had been transferred after the conditioning. The least effective was the conditioning of flowers in benzyladenine at $100 \mathrm{mg} \times \mathrm{dm}^{-3}$, because their longevity increased by a mere 7 days.

The postharvest longevity of leaves of the cultivar 'Sunglow' depended significantly only on the concentration of BA. Whether or not the leaves had been conditioned, their placement in a solution of benzyladenine at concentrations of 50 and $100 \mathrm{mg} \times \mathrm{dm}^{-3}$ decreased their vase life by 5.3-5.8 days. Significantly longer-lasting leaves were obtained only when put in water after four-hour conditioning in gibberellic acid at a concentration of $400 \mathrm{mg} \times \mathrm{dm}^{-3}$ (Table 2).

Table 1.

Postharvest flower longevity of Zantedeschia 'Albomaculata' (days) depending on concentration of benzyladenine and type of solution used after conditioning

\begin{tabular}{cccc}
\hline Concentration of BA $\left(\mathrm{mg} \times \mathrm{dm}^{-3}\right)$ & Water & 8HQS $\left(200 \mathrm{mg} \times \mathrm{dm}^{-3}\right)+2 \%$ sucrose & Mean for concentration of BA \\
\hline 0 & $9.9 \mathrm{a}$ & $24.9 \mathrm{~d}$ & $17.4 a$ \\
50 & $24.4 \mathrm{~d}$ & $20.3 \mathrm{c}$ & $22.3 \mathrm{~b}$ \\
100 & $16.1 \mathrm{~b}$ & $16.8 \mathrm{~b}$ & $16.4 a$ \\
150 & $20.3 \mathrm{c}$ & $21.2 \mathrm{c}$ & $20.8 \mathrm{~b}$ \\
\hline Mean & $17.6 \mathbf{a}$ & $20.8 \mathbf{b}$ & \\
\hline
\end{tabular}

Means followed by the same letter do not differ significantly at $\alpha=0.05$

Table 2.

Postharvest longevity of Zantedeschia 'Sunglow' (days) leaves depending on concentration of gibberellic acid and benzyladenine

\begin{tabular}{|c|c|c|c|c|}
\hline \multirow{2}{*}{ Concentration of $\mathrm{GA}_{3}\left(\mathrm{mg} \times \mathrm{dm}^{-3}\right)$} & \multicolumn{3}{|c|}{ Concentration of BA $\left(\mathrm{mg} \times \mathrm{dm}^{-3}\right)$} & \multirow{2}{*}{ Mean for concentration of $\mathrm{GA}_{3}$} \\
\hline & 0 & 50 & 100 & \\
\hline 0 & $9.3 \mathrm{~b}$ & $3.5 \mathrm{a}$ & $4.0 \mathrm{a}$ & $5.6 a$ \\
\hline 300 & $10.0 \mathrm{~b}$ & $3.6 \mathrm{a}$ & $3.7 \mathrm{a}$ & $5.8 a$ \\
\hline 400 & $12.0 \mathrm{c}$ & $3.6 \mathrm{a}$ & $3.7 \mathrm{a}$ & $6.4 a$ \\
\hline Mean for concentration of BA & $10.5 \mathbf{b}$ & $3.6 \mathbf{a}$ & $3.8 \mathbf{a}$ & \\
\hline
\end{tabular}

Means followed by the same letter do not differ significantly at $\alpha=0.05$

When comparing the leaf greenness index, significant differences were noted in its dependence on the concentration of gibberellic acid used for their conditioning and on the concentration of benzyladenine applied at a further longevity-improving stage (Table 3 ). The conditioning in gibberellic acid had a good effect on the index of leaf greenness.

The postharvest longevity of leaves of the cultivar 'Black Eyed Beauty' depended significantly on both the type of growth regulators and their concentration (Table 4). Irrespective of their concentration, ornamental qualities were kept the longest by leaves conditioned in gibberellic acid; they lasted in a vase for an average of 21.7 days. Benzyladenine, irrespective of its concentration, significantly reduced the postharvest longevity of leaves. What proved ineffective was the combination of the two growth regulators at whatever concentration in a conditioning solution, because the vase life of the leaves was close in this case to that of the control. When 
comparing interactions, ornamental qualities were found to be preserved the longest by those leaves which were conditioned in a $50 \mathrm{mg} \times \mathrm{dm}^{-3}$ solution of gibberellic acid: their vase-life was 30 days. In comparison with the control, their postharvest longevity increased by 15 days. Gibberellic acid at $100 \mathrm{mg} \times \mathrm{dm}^{-3}$ was less effective, as it extended the longevity of leaves by 11 days.

Table 3.

Index of leaf greenness of Zantedeschia 'Sunglow' (SPAD) depending on concentration of gibberellic acid and benzyladenine

\begin{tabular}{ccccc}
\hline & \multicolumn{3}{c}{ Concentration of BA $\left(\mathrm{mg} \times \mathrm{dm}^{-3}\right)$} & Mean for concentration of GA 3 \\
\cline { 2 - 5 } Concentration of $\mathrm{GA}_{3}\left(\mathrm{mg} \times \mathrm{dm}^{-3}\right)$ & 0 & 50 & 100 & $17.4 a$ \\
\hline 0 & $15.7 \mathrm{a}$ & $17.7 \mathrm{ab}$ & $18.7 \mathrm{ab}$ & $21.1 \mathrm{~b}$ \\
300 & $24.6 \mathrm{c}$ & $19.1 \mathrm{~b}$ & $19.5 \mathrm{~b}$ & $21.6 \mathrm{~b}$ \\
\hline 400 & $25.7 \mathrm{c}$ & $18.7 \mathrm{ab}$ & $20.4 \mathrm{~b}$ & $19.5 \mathbf{~ b}$ \\
\hline Mean for concentration of BA & $22.0 \mathbf{~ a}$ & $18.5 \mathbf{~ b}$ & & \\
\hline
\end{tabular}

Means followed by the same letter do not differ significantly at $\alpha=0.05$

Index of initial leaf greenness 68.8

Table 4.

Effect of conditioning in gibberellic acid and benzyladenine on postharvest leaf longevity of Zantedeschia 'Black Eyed Beauty' (days)

\begin{tabular}{|c|c|c|}
\hline Growth regulator & Concentration $\left(\mathrm{mg} \times \mathrm{dm}^{-3}\right)$ & Postharvest longevity of leaves \\
\hline \multirow{3}{*}{$\mathrm{GA}_{3}$} & 0 & $12.0 \mathrm{~b}$ \\
\hline & 50 & $30.0 \mathrm{~d}$ \\
\hline & 100 & $23.0 \mathrm{c}$ \\
\hline \multicolumn{2}{|c|}{ mean } & $21.7 \mathbf{c}$ \\
\hline \multirow{3}{*}{ BA } & 0 & $12.0 \mathrm{~b}$ \\
\hline & 50 & $8.9 \mathrm{a}$ \\
\hline & 100 & $8.2 \mathrm{a}$ \\
\hline \multicolumn{2}{|c|}{ mean } & $9.7 \mathbf{a}$ \\
\hline \multirow{3}{*}{$\mathrm{GA}_{3}+\mathrm{BA}$} & 0 & $12.0 \mathrm{~b}$ \\
\hline & $50+50$ & $11.9 \mathrm{~b}$ \\
\hline & $100+100$ & $12.0 \mathrm{~b}$ \\
\hline \multicolumn{2}{|c|}{ mean } & $12.0 \mathbf{b}$ \\
\hline \multirow{3}{*}{$\mathrm{GA}_{3}+\mathrm{BA}$} & 0 & $12.0 \mathrm{~b}$ \\
\hline & $50+100$ & $12.4 \mathrm{~b}$ \\
\hline & $100+50$ & $13.4 \mathrm{~b}$ \\
\hline \multicolumn{2}{|c|}{ mean } & $12.6 \mathbf{b}$ \\
\hline
\end{tabular}

Means followed by the same letter do not differ significantly at $\alpha=0.05$

The content of chlorophyll $a+b$ in the leaves of cultivar 'Black Eyed Beauty' at the close of the experiment depended significantly on both the growth regulator contained in the conditioning solutions and their concentrations (Table 5). The lowest chlorophyll content was noted in the control leaves placed in water. The highest chlorophyll content was recorded in leaves conditioned in gibberellic acid at $50 \mathrm{mg} \times \mathrm{dm}^{-3}$. A significantly high chlorophyll content was also displayed by leaves conditioned in gibberellic acid at $100 \mathrm{mg} \times \mathrm{dm}^{-3}$. In the remaining treatments in which the leaves were conditioned in benzyladenine or its mixture with gibberellic acid, chlorophyll levels were lower, but even so significantly higher than in the control.

A consequence of the advancing process of leaf senescence is proteolysis, i.e. the degradation of proteins. The statistical analysis showed significant differences in protein content at the end of the experiment on application of growth regulators at various concentrations for conditioning of leaves of the cultivar 'Black Eyed Beauty' (Table 6). Irrespective of their 
concentration, the highest final protein content was recorded in the leaves conditioned in aqueous solutions containing a mixture of gibberellic acid and benzyladenine. A significantly high protein content was also noted in leaves conditioned in gibberellic acid at whatever concentration. When comparing interactions, it was found that the protein level was the highest in the leaves conditioned in the solutions of $\mathrm{GA}_{3}+\mathrm{BA}$ at concentrations of $100+100 \mathrm{mg} \times \mathrm{dm}^{-3}$ and $50+100$ $\mathrm{mg} \times \mathrm{dm}^{-3}$. A significantly high protein content was observed in the leaves conditioned in the $100 \mathrm{mg} \times \mathrm{dm}^{-3}$ solution of $\mathrm{GA}_{3}$ and in $\mathrm{GA}_{3}+\mathrm{BA}$ at a concentration of $50+50$ and $100+50 \mathrm{mg}^{2} \mathrm{dm}^{-3}$. In the remaining treatments, protein degradation looked similar.

Table 5.

Effect of conditioning in gibberellic acid and benzyladenine on chlorophyll $\mathrm{a}+\mathrm{b}$ content in leaves of Zantedeschia 'Black Eyed Beauty' $\left(\mathrm{mg} \times \mathrm{g}^{-1} \mathrm{FW}\right)$

\begin{tabular}{|c|c|c|}
\hline Growth regulator & Concentration $\left(\mathrm{mg} \times \mathrm{dm}^{-3}\right)$ & Chlorophyll $\mathrm{a}+\mathrm{b}$ content \\
\hline \multirow{3}{*}{$\mathrm{GA}_{3}$} & 0 & $0.8 \mathrm{a}$ \\
\hline & 50 & $2.2 \mathrm{~d}$ \\
\hline & 100 & $1.8 \mathrm{c}$ \\
\hline \multicolumn{2}{|c|}{ mean } & $1.6 \mathrm{c}$ \\
\hline \multirow{3}{*}{ BA } & 0 & $0.8 \mathrm{a}$ \\
\hline & 50 & $1.3 \mathrm{~b}$ \\
\hline & 100 & $1.3 \mathrm{~b}$ \\
\hline \multicolumn{2}{|c|}{ mean } & $1.1 \mathbf{a}$ \\
\hline \multirow{3}{*}{$\mathrm{GA}_{3}+\mathrm{BA}$} & 0 & $0.8 \mathrm{a}$ \\
\hline & $50+50$ & $1.2 \mathrm{~b}$ \\
\hline & $100+100$ & $1.2 \mathrm{~b}$ \\
\hline \multicolumn{2}{|c|}{ mean } & $1.1 \mathbf{b}$ \\
\hline \multirow{3}{*}{$\mathrm{GA}_{3}+\mathrm{BA}$} & 0 & $0.8 \mathrm{a}$ \\
\hline & $50+00$ & $1.4 \mathrm{~b}$ \\
\hline & $100+50$ & $1.4 \mathrm{~b}$ \\
\hline & & $1.2 \mathbf{a b}$ \\
\hline
\end{tabular}

Means followed by the same letter do not differ significantly at $\alpha=0.05$

Initial content of chlorophyll $\mathrm{a}+\mathrm{b}-4.0 \mathrm{mg} \cdot \mathrm{g}^{-1} \mathrm{FW}$

Table 6

Effect of conditioning in gibberellic acid and benzyladenine on protein content in leaves of Zantedeschia 'Black Eyed Beauty' $\left(\mathrm{mg} \times \mathrm{g}^{-1} \mathrm{FW}\right.$ )

\begin{tabular}{|c|c|c|}
\hline Growth regulator & Concentration $\left(\mathrm{mg} \times \mathrm{dm}^{-3}\right)$ & Protein content \\
\hline \multirow{3}{*}{$\mathrm{GA}_{3}$} & 0 & $4.4 \mathrm{a}$ \\
\hline & 50 & $4.9 \mathrm{a}$ \\
\hline & 100 & $6.0 \mathrm{~b}$ \\
\hline \multicolumn{2}{|c|}{ mean } & $5.1 \mathbf{b}$ \\
\hline \multirow{3}{*}{ BA } & 0 & $4.4 \mathrm{a}$ \\
\hline & 50 & $4.1 \mathrm{a}$ \\
\hline & 100 & $4.8 \mathrm{a}$ \\
\hline \multicolumn{2}{|c|}{ mean } & $4.4 \mathbf{a}$ \\
\hline \multirow{3}{*}{$\mathrm{GA}_{3}+\mathrm{BA}$} & 0 & $4.4 \mathrm{a}$ \\
\hline & $50+50$ & $7.5 \mathrm{c}$ \\
\hline & $100+100$ & $8.4 \mathrm{~d}$ \\
\hline \multicolumn{2}{|c|}{ mean } & $6.8 \mathrm{c}$ \\
\hline \multirow{4}{*}{$\mathrm{GA}_{3}+\mathrm{BA}$} & 0 & $4.4 \mathrm{a}$ \\
\hline & $50+100$ & $8.5 \mathrm{~d}$ \\
\hline & $100+50$ & $7.4 \mathrm{c}$ \\
\hline & mean & $6.8 \mathrm{c}$ \\
\hline
\end{tabular}

Means followed by the same letter do not differ significantly at $\alpha=0.05$

Initial content of protein $-10.0 \mathrm{mg} \cdot \mathrm{g}^{-1} \mathrm{FW}$ 


\section{DISCUSSION}

Cut flowers display various postharvest longevity depending on species, cultivar, harvesting stage, and cultivation conditions. The vase life of flowers is one of the criteria in assessing their quality. In the experiment reported, flowers of the cultivar 'Albomaculata' put in water preserved their ornamental qualities for a mere 10 days. The reason of such rapid senescence was the greening of spathes caused by the appearance of chlorophyll in them. This phenomenon has already been observed by T j i a and F u nnell (1986), who emphasised that the greening of spathes in the calla lily was the prime reason of the short postharvest longevity of its cut flowers. Still, as shown in a study by J a now s ka and J e r zy (2004), it is not in all cultivars that the spathes turn green, and the postharvest longevity of flowers may even extend to 3-4 weeks.

Hydroxyquinoline esters combined with saccharose are the most popular preservative used to extend the longevity of cut flowers. In the case of geophytes, its effectiveness has been proved, e.g. in Gladiolus (Łukaszewska, 1978), Hippeastrum $x$ chmielii ( $\mathrm{u} \mathrm{k}$ a s zew sk a and I l c z u k, 2001), and Alstroemeria (G o s z c z y ń s k a et al. 1988). In the present study, this preservative applied as a holding solution also proved effective, because the postharvest longevity of 'Albomaculata' flowers improved by as many as 2 weeks. However, a research should be conducted on other cultivars because, as shown in the literature, they can display a variety of responses, as corroborated by J a n ow ska and Jerzy (2004) as well as T j i a and Funnell (1986).

To extend the longevity of cut flowers, ever more frequent use is made of growth regulators from the group of cytokinins and gibberellins. In the research reported, the conditioning of flowers of the cultivar 'Albomaculata' in benzyladenine at concentrations of $50-150 \mathrm{mg} \times \mathrm{dm}^{-3}$ improved their vase-life by 7-14 days.

The effectiveness of benzyladenine in extending the longevity of cut flowers has been proved, among others, in Astilbe $x$ arendsii 'Amethyst' in which benzyladenine applied at a concentration of $400 \mathrm{mg} \times \mathrm{dm}^{-3}$ for 2- and 6-hour conditioning doubled the longevity of inflorescence shoots if the conditioning was followed by a continuous action of a $8 \mathrm{HQS}$ solution at a concentration of $200 \mathrm{mg} \times \mathrm{dm}^{-3}$ with an addition of $2 \%$ saccharose (P o gros zew sk a and S a d k ow ska, 2006). Jakubowska et al. (2000) report that Lathyrus latifolius flowers last longer after 24-hour conditioning in benzyladenine at concentrations of 5 and 10 $m g \times \mathrm{dm}^{-3}$ and a continuous treatment with this growth regulator at $10 \mathrm{mg} \times \mathrm{dm}^{-3}$. A favourable response to benzyladenine has also been observed in Anthurium (Paull and Chantrachit, 2001) and carnations
(W a wrzyńczak and Goszczyńska，2003), while it has been found to have no effect on the postharvest longevity of Ixia (B r z e z i n a et al. 1994).

The process of senescence is different in cut leaves than in flowers, so preparations improving the longevity of cut flowers are often of little effect for leaves (Łukaszewska, 2000; Skutnik et al. 2001); hence the attempts to extend the longevity of cut greenery with the help of growth regulators. The research on the regulation of postharvest longevity started in the 1960s when cytokinins attracted attention as possible factors prolonging the postharvest longevity of vegetables. They were shown to be effective in celeriac and endive (G u z man, 1963) as well as lettuce (Wit twe r and D e d ol ph, 1962). Later, they began to be applied to cut flowers (H e i d e and Oy d vin, 1969; $\mathrm{H}$ a n, 1995) and then florist greens (S k u tnik et al. 2001). Cytokinins are effective in many cases but, as Çe likel et al. (2002) report, their effectiveness declines if they are combined with gibberellin.

In the present research, when comparing the effectiveness of gibberellic acid and benzyladenine in improving the longevity of leaves of the cultivar 'Sunglow', only gibberellic acid turned out to have a good effect: the conditioning of leaves in this growth regulator at a concentration of $400 \mathrm{mg} \times \mathrm{dm}^{-3}$ extended their longevity by 3 days. Moreover, at concentrations of 300-400 $\mathrm{mg} \times \mathrm{dm}^{-3}$ gibberellic acid boosted the index of leaf greenness. Similarly, only this acid proved effective in leaves of the cultivar 'Black Eyed Beauty': at concentrations of 50 and $100 \mathrm{mg} \times \mathrm{dm}^{-3}$ it extended their postharvest longevity. The combination of the two growth regulators in various concentration variants had no effect on the longevity of the leaves. Still, both gibberellic acid and benzyladenine inhibited chlorophyll degradation in the leaves, while gibberellic acid and a $\mathrm{GA}_{3}+\mathrm{BA}$ mixture slowed down the degradation of proteins. $\mathrm{Janowska}$ and $\mathrm{Je}$ r z y (2003a and b) confirmed the beneficial effect of gibberellic acid on the postharvest longevity of leaves and chlorophyll content in cultivars 'Black Magic' and 'Florex Gold'. Ł u k a s z e w s ka (2000) and S k u t n ik et al. (2001), in turn, observed gibberellic acid to have a good effect on Zantedeschia aethiopica leaves: their longevity increased sixfold in comparison with the control, and chlorophyll degradation was inhibited. Similar results were obtained in the leaves of Hippeastrum $x$ hortorum: after conditioning in a solution of gibberellin, their longevity increased as much as eight times ( $\mathrm{Kkutnik,1998;} \mathrm{Łukas} \mathrm{zew} \mathrm{ska,}$ 2000). Gibberellin applied in Alstroemeria effectively inhibited chlorophyll degradation in leaves ( $\mathrm{D}$ a i and Pau 11, 1991; Hicklent on, 1991), while in cut leaves of Lilium longiflorum and Lilium sp. gibberellin slowed down their yellowing ( $\mathrm{H} \mathrm{a} \mathrm{n}, 1995)$; this 
effect, however, was not observed in the leaves left on plants (H a n , 1997).

The effectiveness of a given growth regulator depends on the species and mode of application. As S k u tnik et al. (2004) report, benzyladenine turned out to be less effective than gibberellic acid in improving the longevity of leaves of Zantedeschia aethiopica and Zantedeschia elliottiana. S kutn i k and R a b i z a -Ś wider (2005) demonstrated that the conditioning of $Z$. aethiopica leaves in a solution of gibberellic acid, and Hosta leaves in a solution of benzyladenine mitigated detrimental effects of keeping Z. aetiopica leaves dry and in the dark, and keeping Hosta leaves dry, whether in the dark or light. Besides, in both species this practice greatly extends postharvest longevity. An earlier study of S k u t n i k (1998) shows benzyladenine to be effective in extending the longevity of Hosta leaves conditioned or soaked in this growth regulator, and this also holds for shoots of Asparagus densiflorus 'Sprengerii'. Benzyladenine is also effective in extending the longevity of Arum italicum leaves ( $\mathrm{J}$ a n o w ska and Schroeter-Zakrzewska, 2008).

A consequence of the advancing process of leaf senescence is proteolysis, i.e. the degradation of proteins. There is little information in the available literature on the inhibition of this process after the use of growth regulators. In a research by $\mathrm{R} \mathrm{abiza-Ś} \mathrm{w} \mathrm{i} \mathrm{-}$ $\mathrm{d}$ e $\mathrm{r}$ et al. (2004), leaves of Zantedeschia aethiopica and Zantedeschia elliottiana were subjected to 24-hour conditioning in solutions of benzyladenine and gibberellic acid. In both species only gibberellic acid effectively retarded the degradation of soluble proteins. The standard medium employed to extend the longevity of cut flowers accelerated proteolysis in leaves of Z. aethiopica, but did not show the same unfavourable effect on those of $Z$. elliottiana. A decline in the content of soluble proteins was accompanied by an accumulation of free amino acids. Similarly, in a study by Rabiza-Ś wider and Skutnik (2008), the conditioning of leaves of Hosta 'Crispula' and 'Undulata Mediovariegata' in gibberellic acid and benzyladenine retarded the degradation of soluble proteins, especially readily visible after the use of benzyladenine. In turn, placing Hosta leaves in the standard medium used for cut flowers accelerated proteolysis.

\section{CONCLUSIONS}

1. BA and 8HQS influence the postharvest longevity of calla lily flowers, while $\mathrm{GA}_{3}$ and BA affect the postharvest longevity and quality of its leaves.

2. The conditioning of flowers of cv. 'Albomaculata' in BA at concentrations of $50-150 \mathrm{mg} \times \mathrm{dm}^{-3}$ extends their postharvest longevity by $6.2-14.5$ days. An extension of the longevity of the flowers by 2 weeks can be obtained after the application of a solution of $8 \mathrm{HQS}$ with saccharose as a holding solution.

3. Effective in improving the longevity of leaves of cultivar 'Sunglow' is $\mathrm{GA}_{3}$ at a concentration of $400 \mathrm{mg} \times \mathrm{dm}^{-3}$. What is more, its application at concentrations of $300-400 \mathrm{mg} \times \mathrm{dm}^{-3}$ boosts their greenness index.

4. $\mathrm{GA}_{3}$ at concentrations of 50 and $100 \mathrm{mg} \times \mathrm{dm}^{-3}$ extends the postharvest longevity of leaves of the cultivar 'Black Eyed Beauty', while BA shortens it. A combined application of $\mathrm{BA}$ and $\mathrm{GA}_{3}$ inhibits chlorophyll degradation, while $\mathrm{GA}_{3}$ and a mixture of $\mathrm{BA}$ and $\mathrm{GA}_{3}$ inhibit protein degradation.

\section{REFERENCES}

Arnon D. J., 1949. Cooper enzymes in isolated chloroplasts. Polyphenoloxidase in Beta vulgaris. Plant Physol. 24: $1-15$.

Bradford M.M., 1976. A rapid and sensitive method for the quantitation of microgram quantities of protein utilizing the principle of protein-dye binding. Anal Biochem. 72: 248-254.

Brzezina M., Piskornik Z., Piskornik M., 1994. The effect of sucrose, cytokinins, and selected inhibitors of ethylene biosynthesis and action on the longevity of cut ixia flowers. Folia Hortic. VI/2: 63-70.

Çelikel F.G., Dodge L.L., Reid M.S. 2002. Efficacy of 1-MCP (1-methycyclopropene) and Promalin for extending the post-harvest life of Oriental lilies (Lilium $\times$ 'Mona Lisa' and 'Star Gazer'). Sci. Hortic. 93:149-155.

Dai J.W., Paul1 R.E., 1991. Postharvest handling of Alstroemeria. HortScience, 26: 314.

Goszczyńska D.M., Michalczuk B., Rudnicki R.M., 1988. Postharvest physiology of Alstroemeria flowers I. Evaluation of keeping quality of cut Alstroemeria 'Harmony' flowers after chemical treatment. Prace ISiK, B, 12: 125-129.

Gregorczyk A., Raczyńska A., Pacewicz K., 1998. Analiza krzywych wzorcowych zawartości chlorofilu dla podstawowych gatunków zbóż. / Analysis of standardisation curves of chlorophyll content for the basic grain species. Biul. Magnezol. 3(1): 19-24 (in Polish).

Gregorczyk A., Raczyńska A., 1997. Badania korelacji między metodą Arnona a pomiarami zawartości chlorofilu za pomocą chlorofilometru. / Study of the correlation between Arnon's method and measurements of chlorophyll content using a chlorophyll meter. Folia Univ. Agric. Stetin.181. Agricult. 5: 119-123 (in Polish).

Guzman V.L., 1963: Concentration of N6 benzyladenine, temperature, and time effects on retardation of senescence in celery and endive. Proc. Fla. State Hort. Soc. 75:196-201.

H a n S.S., 1995. Growth regulators delay foliar chlorosis of Easter lily leaves. J. Amer. Soc. Hort. Sci. 120: 254-258.

Han S.S., 1997. Preventing postproduction leaf yellowing in Easter lily. J. Amer. Soc. Hort. Sci. 122: 869-872. 
Heide O.M., Oydvin J., 1969. Effects of 6-benzylamino-purine on the keeping quality and respiration of glasshouse carnations. Hort. Res. 9:26-36.

Hiscox J.D., Israelstam G.F., 1979. A method for the extraction of chlorophyll from leaf tissue without maceration. Can. J. Bot. 57: 1332-1334.

Hicklenton P.R., 1991. GA 3 and benzylaminopurine delay leaf chlorosis in cut Alstroemeria stems. HortScience, 26: 1198-1199.

Jakubowska A., Piskornik A., Świderski A., 2000. Przedłużanie trwałości ciętych kwiatów groszku szerokolistnego (Lathyrus latifolius L.). / The postharvest longevity of Lathyrus latifolius. Zesz. Nauk. AR w Krakowie 364: 293-296 (in Polish).

Janowska B., Jerzy M., 2003a. Effect of gibberellic acid on post-harvest leaf longevity of Zantedeschia elliottiana (W. Wats.) Engl. J. Fruit Ornamental Plant Res. 11: 69-76.

Janowska B., Jerzy M., 2003b. Effect of gibberellic acid on the quality of cut leaves of Zantedeschia elliottiana (W. Wats.) Engl. Acta Scien. Pol., Hortorum Cultus, 2(1): 85-94 (in Polish).

Janowska B., Jerzy M., 2004. Effect of gibberellic acid on post-harvest flower longevity of Zantedeschia elliottiana (W. Wats.) Engl. Acta Scien. Pol., Hortorum Cultus, 3(1): 3-9.

Janowska B., Schroeter-Zakrzewska A., 2008. Effect of gibberellic acid, benzyladenine and 8-hydroxyquinoline sulphate on post-harvest leaf longevity of Arum italicum Mill. Zesz. Probl. Post. Nauk Roln. 525: 181-187.

Łukaszewska A., 1978. Wpływ wybranych substancji chemicznych na trwałość i dekoracyjność ciętych mieczyków. / The effect of the exogenously applied chemicals on keeping qualites of cut gladioli. Prace ISiK, B, 3: 69-79 (in Polish).

Łuk a s zew ska A., 2000. Przedłużanie trwałości ciętej zieleni. / Extending the longevity of Florist' green. Ogrodnictwo, 1: 19-21(in Polish).

Łukaszewska A.J., I1czuk K., 2001. Wpływ kwasu giberelinowego na posprzętną jakość ciętych kwiatów zwartnicy (Hippeastrum Herb.). / Effect of gibberellic acid on the postharvest quality of cut Hippeastrum Herb. Flowers. Rocz. AR Pozn. CCCXXXII, Ogrodn. 33: 93-102 (in Polish).

Łukaszewska A.J., Kokosa A., 1997. Przedłużanie trwałości ciętych kwiatów geofitów. / Extending the longevity of cut geophyte flowers. Ogrodnictwo, 2: 19-20 (in Polish).

Paull R.E., Chantrachit T., 2001. Benzyladenine and the vase life of tropical ornamentals. Postharvest Biol. Technol. 21: 303-310.

Pogroszewska E., Sadkowska P., 2006. Wpływ kwasu giberelinowego i benzyloadeniny na trwałość ciętych pędów tawułki Arendsa (Astilbe $\mathrm{x}$ arendsii Arends) 'Amethyst'. / The effect of gibberellic acid and benzyladenine on the longevity of cut inflorescences shoots of Astilbe x arendsii Arends 'Amethyst'. Zesz. Probl. Post. Nauk Roln. 510: 489-496 (in Polish).

Rabiza-Świder J., Skutnik E., 2008. Wpływ substancji chemicznych na starzenie się cietych lisci funkii (Hosta L.) 'Crispula' I 'Undulata Mediovariegata'. / Effect of chemicals on senescence of cut leaves in Hosta L. 'Crispula' i 'Undulata Mediovariegata'. Zesz. Probl. Post. Nauk Roln. 525: 351-360 (in Polish).

S k u t n i k E ., 1998. Gatunki stosowane na zieleń cietą i próby przedłużania ich pozbiorczej trwałości. Konf. „Najnowsze metody przedłużania trwałości ciętych kwiatów." Warszawa. Materiały: 45-50 (in Polish).

Skutnik E., Łukaszewska A., Serek M., Rabi$\mathrm{z}$ a J., 2001. Effect of growth regulators on postharvest characteristics of Zantedeschia aethiopica. Postharwest Biology and Technol. 21: 241-246.

Skutnik E., Rabiza-Świder J., 2005. Effect of pulsing with growth regulators on senescence of the detached cold-stored leaves of Zantedeschia aethiopica Spr. and Hosta 'Undulata Erromena'). Acta Scien. Pol. Hortorum Cultus, 4(2): 101-110.

Skutnik E., Rabiza-Świder J., Wachowicz M., 2004 Senescence of cut leaves of Zantedeschia aethiopca and Z. elliottiana. Part I. Chlorophyll degradation. Acta Scien. Pol., Hortorum Cultus, 3(2): 57-65.

Tjia B.O., Funnell K.A., 1986. Postharvest studies of cut Zantedeschia inflorescences. Acta Hort. 181: 451-458.

Wawrzyńczak A., Goszczyńska D.M., 2003. Effect of pulse treatment with exogenous cytokinins on longevity and ethylene production in cut carnations. J. Fruit Ornam. Plant Res. 11: 77-88.

Wittwer S.H., Dedolph R.R., 1962. "Youth" hormone keeps vegetables fresh longer. American Vegetable Grower, 10 (3):15, 54-55.

\section{Wpływ regulatorów wzrostu na trwałość pozbiorczą ciętych kwiatów i liści cantedeskii (Zantedeschia Spreng.)}

\section{Streszczenie}

Kondycjonowanie kwiatów cantedeskii odmiany 'Albomaculata' w roztworze BA o stężeniu 50-150 $\mathrm{mg} \times \mathrm{dm}^{-3}$ wydłuża ich pozbiorczą trwałość o 6,2-14,5 dni. Wydłużenie pozbiorczej trwałości kwiatów o 15 dni uzyskuje się po zastosowaniu roztworu $8 \mathrm{HQS}$ z sacharozą w sposób ciągły. W przedłużaniu trwałości liści odmiany 'Sunglow' skuteczny jest $\mathrm{GA}_{3}$ o stężeniu $400 \mathrm{mg} \times \mathrm{dm}^{-3}$. Zastosowanie go w stężeniu 300-400 $\mathrm{mg} \times \mathrm{dm}^{-3}$ zwiększa ponadto indeks zazielenienia liści. $\mathrm{GA}_{3} \mathrm{o}$ stężeniu $50-100 \mathrm{mg} \times \mathrm{dm}^{-3}$ wydłuża pozbiorczą trwałość liści odmiany 'Black Eyed Beauty' odpowiednio o 18 i 11 dni, a BA - obniża ją. Łączne stosowanie BA i GA hamuje degradację chlorofilu, a $\mathrm{GA}_{3}$ oraz mieszanina $\mathrm{BA} \mathrm{i} \mathrm{GA}{ }_{3}$ hamuje rozpad białka. 